\section{In review}

\section{Roderick J McClure}

The end of the year is a conventional time to take stock and assess ones performance over the preceding 12-month period. Comparisons are invariably the currency of these evaluations. Both the notion of evaluation, and the use of comparisons as a tool for undertaking it, are appropriate. The usefulness of the evaluation effort depends on the way the performance questions are framed, and the relevance of the comparisons being made.

As scientists, we are all aware of the importance of getting the research question right. First the question, and after that the rest. As scientists, comparisons are our tools of trade. Epidemiologists are people who compare rates. Importantly, it is 'rates' not 'counts'. Discussion is endlessly had over which rate is the right comparison.

From comparisons, we clarify sets of correlations unencumbered by alternative explanations and draw inferences about causation. This process is simpler in controlled research environments than in societal contexts. It is simpler too, in steady state environments than dynamic ones.

One assessment of the performance of scientific journals is the journal impact factor, published by Clarivate. ${ }^{1}$ Injury Prevention's impact factor for 2017 (announced end of July 2018) was 163\% higher than for 2016. The number of manuscript submissions to Injury Prevention in 2018 was similar to 2017. Times from submission to decision and, publication have decreased. Traffic to the journal website has been higher in 2018 than in previous years.

These comparisons provide useful information within a limited visual field. The real question the journal's self-performance review should be asking is, how

Correspondence to Dr Roderick J McClure, School of Rural Medicine, University of New England, Armidale, NSW 2351, Australia; rmcclure@une.edu.au is the world different because the journal was here?'

This is altogether a different kind of question. It may be too difficult a question to answer, but it is a useful question nonetheless. In attempting to answer this question, we just may change the way see ourselves as scientific authors and publishers, and possibly ensure that in 2019, we make a bigger impact than before.

A better world is not a counterfactual we can substitute for the real one. Making a difference is not a matter of holding all variables in the world constant, except the one we are interested in changing, changing it and quantifying the before and after gap. Societal change is achieved by constraining growth in any one direction and supporting growth in another. Our outcomes depend on our starting point. If Injury Prevention is to make a difference to the health and well-being of global populations, then Injury Prevention will be a catalyst for helping communities evolve. $^{2}$

In 2018, the journal's editorial processes sought to select manuscripts of the highest quality that provided information of high relevance to prevention practice. Editors made an effort to broaden the range of injury topics published, and the breath of methodologies employed. Manuscript selection actively encouraged publication of research from diverse communities from across the globe. Social media engagement was enhanced. A new series of regular podcasts was launched. An education section of the journal was established. The journal commissioned a series of state-of-the-art reviews, which will begin to appear in press from 2019. These reviews will be focused on the edge of current knowledge, at the places where editors feel the field should be pushing into new ground. State-of-the-art reviews will summarise existing evidence, include science from new disciplines, explore new applications and broach new topics. The reviews will be 'go to' papers for people developing new frontiers in the field.

Finally, I am pleased to announce that Injury Prevention will become an online only journal from 2019. The journal will continue to have the same high quality production standards and rapid publication times, but given that most readers now only access the journal digitally it makes sense for us to move to a publication format that allows greater flexibility with regards to the amount of content that we can publish in each issue.

Reflecting on ones performance over a preceding 12-month period is not an end in itself, but part of an iterative learning process that leads to further improvement and greater ends. Editorial initiatives undertaken in 2018 were designed to grow Injury Prevention's relevance to the scientific, practitioner and public communities the journal serves. Like the world around us, Injury Prevention is evolving.

Funding The authors have not declared a specific grant for this research from any funding agency in the public, commercial or not-for-profit sectors.

Competing interests None declared.

Patient consent Not required.

Provenance and peer review Not commissioned; internally peer reviewed.

(C) Author(s) (or their employer(s)) 2018. No commercial re-use. See rights and permissions. Published by BMJ.

\section{(A) Check for updates}

To cite McClure RJ. Inj Prev 2018;24:395.

Published Online First 14 August 2018

Inj Prev 2018;24:395.

doi:10.1136/injuryprev-2018-043038

\section{REFERENCES}

1 The Clarivate Analytics, 2018. The clarivate analytics impact factor. Available from: https://clarivate.com/ essays/impact-factor/ [Accessed accessed 8/10/2018].

2 McClure RJ, Adriazola-Steil C, Mulvihill C, et al. Simulating the dynamic effect of land use and transport policies on the health of populations. Am J Public Health 2015;105 Suppl 2(Suppl 2):S223-9. 